\title{
ARNHEIM'S THEORY OF AESTHETICS AND FIGURES OF SPEECH
}

\author{
Dario Saftich, $B A$ \\ e-mail: dario.saftich@htnet.hr \\ Edit, Rijeka (Croatia)
}

\begin{abstract}
A b s tract
Upon its publication in 1932, German scientist Rudolph Arnheim's work "Film as Art"represented a significant contribution to the theoretical debate regarding film as an art. Arnheim himself was one of the first to open the debate: he opposed the accepted exclusion of film from the domain of the arts. According to Arnheim, there are great differences between the perception of reality and the perception of its reproduction upon a film screen, and it is within these very differences that one should seek out the artistic possibilities available to film. In this context, Rudolph Arnheim doesn't refer to film figures, but does however anatomize theoretical assumptions and examples in film, which he then lists as attributes to the theory of film as art. Literary figures, Arnheim additionally explains, cannot be mechanically transferred into film figures. However, the director can become an artist who will depict to us the world not as it objectively looks, but subjectively as well: he is in a position to create new realities, evoke magical worlds, and build symbolic bridges between facts and things that lack any direct ties in real life. Rudolph Arnheim transferred the notion of Gestalt, as developed by Gestalt psychology, to aesthetics.
\end{abstract}

Keywords: film, art, reality, perception, reproduction, film figures, literary figures, aesthetics

\section{Introduction}

Upon its publication in 1932, German scientist Rudolph Arnheim's work "Film as Art"represented a significant contribution to the theoretical debate regarding film as an art. Arnheim himself was one of the first to open the debate: he opposed the accepted exclusion of film from the domain of the arts. The German scientist indirectly replied to complaints often attributed to film, that it implies a mechanical, passive, reproductive reality, a sort of "machine"for printing life. According to Arnheim, the situation is drastically different: there are great differences between the perception of reality and the perception of its reproduction upon a film screen, and it is within these very differences that one should seek out the artistic possibilities available to film. In this 
context, Rudolph Arnheim doesn't refer to film figures, but does however anatomize theoretical assumptions and examples in film, which he then lists as attributes to the theory of film as art. An indirect and surprising tie is thus revealed, one between its own visions of the possible artistic achievements in film and the figures of speech within film. The key concept, in that sense, is "symbolic content".

\section{"Symbolic Content"}

Rudolph Arnheim states: "In most cases, as mentioned, such symbolic occurrences are also motives to a story that is plausible in reality. It is rare that symbolic content be a goal in itself - like in Abel Gance's Napoleon, in which a giant, transparent image of the female form appears in double exposition above a revolutionary sight, or the enormous bull that appears high in the sky over grazing cows in Eisenstein's work. Such an abstract addition of elements, which the artist often experiences with the help of the appropriate form that presents objects which do not belong together - i.e. so that one is presented in double exposition over the other - is usually not very effective. When Lupu Pick underlines the passionate experience between three people by inserting an image of a tumultuous sea in New Year's Eve, it is a metaphor which could even be sufficient in literature (think of Homeric allegory), because the poet does not serve us with a direct perspective, but by one employed by the film artist. In a movie image, two components of comparison are not capable of forming unity ". (Arnheim, 1997, 82)

Literary figures, Arnheim additionally explains, cannot be mechanically transferred into film figures. However, the director can become an artist who will depict to us the world not only as it objectively looks, but subjectively as well: he is in a position to create new realities, evoke magical worlds, and build symbolic bridges between facts and things that lack any direct ties in real life. The yearning to faithfully depict all that is unusual, characteristic and exciting in our world lies in the very nature of film. Film art - according to Arnheim's theory - began to gradually develop only at the moment when creators of film, consciously or unconsciously, advanced specific possibilities of film technique, applying them to the creation of works of art. In order to create a work of art, the film artist must consciously use the specificities of film instead of other means of expression. This should be done by expressing the nature of depicted objects more forcefully. Numerous attributes of film material can be utilized to achieve artistic effects.

\section{Review of Arnheim's Aesthetic Theory}

Rudolph Arnheim transferred the notion Gestalt, as developed by Gestalt psychology, to aesthetics. In the book Art and Visual Perception he uses the term "configuration" (shape). To him it represents the foremost and simplest aspect of perception, a perception that is not only something sensory which then becomes 
conceptual during the process of generalization, but one that appears as a general conceptual formation from the very first moment. If I were to say, see a dog, it would appear to me at the very beginning from the aspect of "doglikeness". And so Arnheim reveals elements in the sensory form which conjoin it with the more abstract, higher mental and spiritual matters. To observe means to create "perceptive concepts", each outside vision is in itself already an inner vision which comprehends the object as a three-dimensional whole; this three-dimensional whole has unchangeable configurations and is not limited to a concrete direction of projection. Configuration never reveals facts about an individual object, i.e. the category to which the object belongs; it is not the form of a single object, but a whole class of things. A related concept is SCHEME, a term it differs from because it considers the active side of experience as vital. Arnheim is not so interested in repetition and patterns as he is in exploring the world, simplification, integrity and the importance of experience.

And configuration is simply the most immediate moment of vision, alongside it and with it an image will appear as a form of some content. It is with form that we truly begin to encroach into the realm of art, which transforms an object into a picture. In that sense, Arnheim strictly protests against artistic naturalism which considers image to be a naive following of reality. For example, Arnheim considers death masks and plaster casts formless, seeing them as how they are is not a result of invention; naturalist orientation, which arose in Western art with the appearance of Renaissance perspective, forgets the difference between reality and image and so considers art as simply a cast of what the artist's eye finds interesting. But the very foundation of art is just that: invention, and not the invention of motive or configuration, but the invention of form: its strength lies in imagination, the imagination which Arnheim determines as an activity which renders the transference of things into images possible. Thus, Arnheim uses a term which will later become a key in the further development of aesthetic form: this notion is medium. Each form should be extracted from the concrete medium within which the image is formed. The relationship between an image and the depicted object is not immanently formal, as is convinced naive naturalism, but the mutual relationship between images within the given media; in order to understand the form of an image of the Grand Canyon, we must compare it to other landscapes. But this doesn't mean that every medium is closed upon itself. Arnheim allows the possibility of translation from one medium to another. However, this can only be successful if we have mastery of both mediums: Leonardo's scientific drawings serve as an example of translation of scientific knowledge into artful depiction. It is therefore possible to translate every abstract argumentation into a visible form, which then as such truly becomes a part of visual conception.

In the book Visual Thinking, this relationship is sharpened further and it is claimed that thinking, in general, is in its essence visual. With this thoughtform, Arnheim sets himself in opposition to those loyal to aesthetics of the enlightened: it is entirely senseless to seek forms which will transcend sensory limitations, seeing as how the spiritual is in itself sensory and formal. 


\section{Arnheim's Film Theory}

Arnheim's aesthetic theory belongs with the traditional aesthetic theories of film. His specific approach to film is aesthetically founded on the principles of silent film. He advocates film as an art and in that context doesn't trust technical advances too much: he is convinced that the development of technical achievements drastically decreases "distinguishing factors"and as such closes the gap between a film image and the real, natural image, actually decreasing the space for developing originality and thus narrowing the area available for artistic achievement in cinematography.

Arnheim treats film as an absolutely visual means of expression, proving that it is exactly those the specificities which make a perfect reproduction of reality upon the canvas impossible, that play the deciding role in forming film's artistic achievement. In other words, film's artistic expression stems from the difference between that which we receive through our senses from reality and the experience evoked within us by moving images on a screen. Arnheim's process is based on the proof of "deviation"between the film image and the object it is showing. This deviation, according to Arnheim's view, is a result of the point of observation, i.e. filming the object, reducing depth, deforming proportion and shape, lighting and the absence of color, a limited field of vision within the shot, absence of space-time continuity, the partiality of an illusion which creates the impression of real life and the imprint of the illusion simultaneously.

Arnheim is convinced that, in good films, each shot must contribute to the plot, and those things which are not creatively motivated are unnecessary in an artistic film. According to his theory, aesthetic values become imperative when a specific film solution, along with the justification of events, acquires a symbolic meaning, thus deepening the purpose of the plot. Other shots, less valuable aesthetically, register the plot and "lead" to the symbolic scene. With this we get an authentic film reality, instead of a mere copy of life. Arnheim was convinced that silent film, thanks to its "deviation" and limitations, succeeded in being true art.

The strength of Arnheim's theory is based on the visual effect of film shots and its deviation from an objective reality. However, Arnheim was convinced that he wasn't speaking of exceptions, but of the central guidelines of artistic creation, or at least those guidelines which should be central.

The question often asked relates to the possible connection between Arnheim's aesthetic theory of film and the theory of stylization and figures of speech. Speaking of interpreting the understanding of style as stylization, Hrvoje Turković states that the key style traits are the traits of certain movies which deviate from the dominant, usual, mutual traits; its is only through exceptional traits that the individuality of a film will be discerned, while this will be impossible if we only have regular traits at our disposal. (Turković, 2005, 233) Therefore, it is deflection, deviation and exceptionality which specify individuality as opposed to everything else, which remains supra-individual. According to Turković, such an understanding of style can be called stylization, because it is in just that, stylization, and coherent deviation from that which is authorial, usual and expected that one finds the essence of style. (Turković, 2005, 233) 
According to this understanding, it is the task of critics, historians and theoreticians to find and interpret stylization and figures of speech: film theories will focus on exactly those characteristics which become evident with rhetorical deviation, while all other dominant, rhetorically unemphasized and unmarked (in terms of style) traits will be held irrelevant, both theoretically and in terms of media. Although very attractive and often practiced, the stylizational conception of individuality and style has obvious drawbacks. The most important limitation is due to the fact that one cannot speak independently of exceptions, deviation, and deflection from that which is dominant. Namely, discerning deviation brought into a film by figures of speech depends on discerning that which is normal, usual in a given context in which the very deviation appears. A film director has many opportunities to, by utilizing imagination, express his subjective vision of the situation and as such deviate from a "normal situation". Figures of speech, in that sense, become a means of expressing the artist's personality.

Bringing the theme up of the reception or experience of film has always been present whilst pondering film. Theoretically, it has been developed - writes Turković through an aesthetic approach to film. The aesthetic approach considers the aesthetic experiences as those with remarkable value and which separate themselves from the context of non-aesthetic experiences. Categorized among non-aesthetic experiences are most everyday cognitive operations, as well as a significant part of film reactions which we feel has no real specific, distinguishing value. Also unable to be classified as aesthetic acts, are all those which serve to awaken our fixed, routinely cultivated mechanism, our inner "automations" and as such actually "block" those places from being experienced as exceptional, distinguishing places of special value. This is why, emphasizes Turković, aestheticians pay special attention to unseen aspects (according to form, structure, style) because it is these aspects that are the potential carriers of articulation of the aesthetic experience, in terms of using these formal aspects (expressive elements and actions) through which they acquire an experiential prominence, and those films in which the experiential goal is not presenting and describing scenes, but where the presented image is subject to other experiential goals, i.e. expression.

Therefore, we can freely state that aestheticians are careful observers who are unwilling to passively accept that which is offered. They will search out interesting transitions in montage which awaken associations, develop imaginations and grant the viewer an important role while he is watching the film. An aesthetician's attention will be drawn by expressly discontinued transitions, those in between scenes, i.e. those in which an imaginary space was either "constructed", or in which continuity was distorted, in other words stylized with the use of contrast. It is originality, exceptionality within the context of other films and typical guidelines, which is desirable in film, explains Turković: a film will be considered aesthetic only through those traits by which it exempts itself from the rules, typical traits, other forms of art, other idiosyncrasies... Therefore, aestheticians will therefore pay special attention to perturbations and deviations from the rules and norms. (Turković, 1994, 20) Here we observe the importance of the mediums which Arnheim spoke of: medium dictates form, that is why aestheticians will be interested in the "specificities" of film, i.e. the 
"filmability" of a film. An aesthetician will refuse to accept those qualities which are also present in other arts as aesthetically relevant or decisive. And finally, all film qualities which are general in terms of style, which appear in many films and appear to be mandatory or typical will not be considered as aesthetically relevant by an aesthetician. Arnheim would say that in that case, we cannot speak of true art.

\section{Figures of Speech}

The basic thesis which can be accepted as such is that "film creation" comes down to the exclusion of figures of speech.

Figures of speech are a certain "meaningful exception": they appear unexpectedly in a given immediate context. They are an exception along with other types of processes in film: optical links, out of shot written and spoken lingual statements, accompanying out of shot music, generally any type of stylization, i.e. an unusual presentation of a scene. However, these exceptions appear in "expected"places: they are the appearance of the "unexpected"in an "expected" place. They appear where additional help is typically necessary for the better understanding of presentation structure: they are a sort of meta-discursive aid. Figures of speech are mostly a complex phenomenon; very contextual preparation is necessary for their comprehension, as well as activation of meaningful linkage during presentation.

In theoretical tradition, both literary and film, figures of speech, as well as some other processes in the composition of presentation, hold true to the rhetorical aspect, the matter of rhetoric. Turkovic notes that the result of the selectivity of the aesthetic approach is that it mostly deals with the rhetorical aspects of film, i.e. mostly stylizations and figures of speech instead of "unmarked regular"actions. In other words, it deals primarily with those films and film currents in which stylistic, rhetorical, and figurative orientation is emphasized. However, the problem characteristic to this approach, emphasizes Turković, is the incapability and impossibility of seeing that regularities and orderliness also rule within rhetoric, because otherwise, rhetorical actions wouldn't even be recognizable and it would be impossible to systematically seek them out.

In a narrative film, figures of speech need not even be present. The given place doesn't necessarily need to be solved with the help of figures of speech, but with the "expected"solution: the appearance of figures is therefore optional. We recognize figures of speech by the absence of following the characters, whose movement is still rendered important by the very obvious withdrawal of their monitoring. The importunity of this absence drives us to accept the implication that it serves a purpose. In order to build a figure of speech, what is expected (and how intensively) should be determined at a given place, and there should be introduced a deviation obvious enough from the expected. It is also necessary to prepare contextual indicators for interpreting the function of the deviation. 


\section{Arnheim's Example}

Emphasizing specificities, deviating from an "objective reality", is the foundation of Arnheim's analysis of film as an art. Film is an account, an expression of creative vigor. The artist makes it in order to give form to: his feelings on the world, his worldview or his understanding and comprehension of self, and in order to develop and elaborate his sensibility.

Within the bounds of expressive comprehension of modernist film, creationism is tied to "exceptions", deviations from the "conventional". However, setting down guidelines for these deviations (stylization) is also of a creative nature. According to Arnheim's basic approach, it is very dangerous for a director to fall under the influence of great similarity between filmed material and reality. The author of a film must not be satisfied with a bland, mechanical reproduction of the real world. A film becomes art if limitations, elements of linkage and other elements not necessarily ideal for the depiction of reality, are creatively utilized. Different viewpoints, interventions which stand out from viewer's "normal" expectations as well as other deviations and "limiting factors" can all be used in the composition of a purpose. They all implicate innovative creation.

The first and main example cited by Arnheim is Charlie Chaplin's "Immigrant". The initial scene in this film is of a rocking boat. The people on deck are displaying clear signs of seasickness: they are all ill. The passengers stagger to the deck's railing and place their hands over their mouths. Then we see the first shot of the main character, Charlie Chaplin, filmed from behind. In fact, we see a man leaning over the railing with his back to the audience, wildly thrashing his legs. We cannot see exactly what he is doing, although we assume he is vomiting, i.e. paying his debt to the sea. This would appear logical, if we take the situation occurring on deck into account. Then suddenly Charlie Chaplin rises, and turns around, content and happy, and reveals to us that he has actually caught a big fish.

The element of surprise is achieved due to the audience viewing the situation from a specific position. Arnheim emphasizes that the thought now hiding behind this scene is no longer the man is doing so and so, for example - fishing or acting ill, but that man is doing so and so, and the viewer is observing him from an exclusively predetermined viewpoint. (Arnheim, 1962, 39) The most expected viewpoint in this context would be if we were seeing Charlie Chaplin fishing, as we clearly see what all the other characters on the deck are doing. However, surprise occurs only when the scene is unexpected, in this case filmed from behind. This is proof that deviation from an expected situation can be used in order to extract a creative solution. Deviation of a figure of a film becomes film creativity because one specific quality of the film technique is used to achieve an unexpected effect.

Without the element of surprise we couldn't really speak of true artistic creation, but of mere reproduction of reality: it is important in this situation that the viewer is not immediately privy to what is occurring in reality. In order to perceive the back shot we must be prepared to interpret it as vomiting. Before that, we must receive the necessary information in order to achieve the effect of surprise. In other words, to achieve creative 
atmosphere, "uncreative preparation" is necessary.

Without figures of speech, this scene would most likely not be memorable. The appearance of figures is not arbitrary: here it contributes to the marking of that important point in the film's presentation. The absence of figures would not compromise the narration, but we would be left without a metadiscursive point of orientation of sorts, in terms of this scene's importance within the total whole of the film's presentation.

The same viewpoint as in Chaplin's example appears in Ewald Andreas Dupont's "Varieté,, at the moment of the main character's appearance. The viewer observes the inmate Jannings from behind during a police interrogation. His face is unseen, only visible is his wide back with a giant number sewn onto his coat. More than enough to bring across a certain thought, that he is "nothing more than a number", just one amongst the crowd without a personality of his own. The same effect as in "Immigrant" is achieved by filming the convict from behind. This effect is more than sufficient for the scene to remain memorable. In this case, according to Arnheim, it is completely irrelevant whether the director actually wanted to render the inmate a symbol, or if he happened to accidently see an inmate from behind, and therefore received inspiration for such a scene. The only important factor is the final artistic effect he succeeded in achieving, without regard to the initial idea or intention. Here we also witness deviation from the expected situation because we see the face of a police officer, which as such has a personality, while the inmate must make do with a number. The number becomes a symbol of his persona. Hence, we have a figure of speech.

Filming angles can play an important role in achieving a certain effect. In old Russian films, the superior strength of a certain persona is expressed through filming them from below. In other words, the camera observes, a general for example, from below like a mountain. According to Arnheim's words, this leads to achievement of an artistic effect: the oddness and unexpectedness of the viewpoint enhances the character's overall effect on the viewer and creates a mesmerizing play on shapes. In this case, figures of speech become evident due to the unexpected viewpoint. In the mentioned situation, an artistic effect is achieved through these figures. The matter close at hand is once again deviation from a "normal" narration because theoretically, the director could've simply settled for the statement that the character is a general. In that case, it would be a case of narration lacking any special stylistic markers, and thus, according to Arnheim's comprehension, any artistic achievements.

Reduction of depth, according to Arnheim's assertion, can also be artistically utilized, because lack of depth adds an element of unreality to the film image. Formal values such as composition and objects' evocative meaning are capable of imposing themselves on the viewer's attention in the absence of deep perception. In that context, Arnheim calls upon the well known scene of a suddenly approaching locomotive. It appears that it will run into the viewers. The more it approaches, the bigger it seems. Such an apparent altering of an objects size, which in reality has remained the same, underlines its actual activity, explains Arnheim, and helps the film artist in visually interpreting the results of that activity. 
Naturally, the viewer does not expect the locomotive to rush towards them. A rushing train on tracks does not make an impression because there isn't a single viewer who hasn't witnessed a train within normal circumstances. An obvious enough deviation from the expected occurs only if the train "focuses"its mass and speed upon the viewer. As such, a condition for the formation of a figure of speech is created, due to, in this case, the use of the techniques of depth reduction and quick changing of natural proportions.

According to Arnheim's theory a director can artistically utilize lighting and the absence of color: he considers this one of the most important aesthetic possibilities of film. In Sternberg's film "The Docks of New York", notes the German scientist, the two main actors are characterized in an obvious manner: white faces, white suits and white hair visually distinguish the girl from the black figure of the ship stoker. Thanks to an ably and skillfully realized harmony, the two characters' game materializes exclusively through the elements of visual perception, i.e. the black and white smudges moving across the screen. Instead of the actors, or characters, we see smudges: the director has clearly created a figure of speech, metonymy, because instead of people, shadows move. We see an evident deviation from the expected situation because up until then, the viewer was able to clearly distinguish the characters' details and their differences. But the effect of "symbolizing" the characteristic colors of the two characters with the help of smudges leaves a striking impression on the viewer and helps him to understand better the contrast in the relationship between the girl and the ship stoker. Naturally, Arnheim doesn't even mention figures of speech, but is rather convinced that the artistic possibilities of black and white film became evident here, ones which wouldn't be possible, according to him, in color film.

Arnheim also believes that shots and distance from the given object can be artistically used. In film, the only things that are visible are those which are within the shot and that, explains the German scientist, affords the film artist the opportunity to choose from an endless abundance of real life. Shot, as well as perspective, is a "tool" for formation because it allows a significant detail to be "extracted" and thus handed an explicit meaning, or a certain surprise to suddenly enter the shot. In other words, what Arnheim is saying can be interpreted as violating the expected, introducing a "surprise", i.e. an obvious enough deviation from an expected situation. Arnheim practically provided a definition for figures of speech using a completely different repertoire of sentences. What he considered to be the artistic accomplishment of the film was in fact figures of speech. In that context, let us move on to a specific example. Once again, in "The Docks of New York", we have a scene of a woman and man, in this case a love scene between a sailor and a prostitute. They sit and drink, not displaying signs of mutual affection. Then appears a close-up: an uncomfortable detail. The woman is caressing the sailor's arm which is completely tattooed with vulgar images. According to Arnheim, was the same scene filmed as a full shot, it wouldn't have been nearly as effective. Instead of seeing a man onscreen, we see only an arm, firm, naked and vulgarly decorated, symbolizing what the man represents to this woman: only strength, nudity, muscle. The director applies the principle "pars pro toto", says Arnheim. And "pars pro toto", we may add, is one of the keys to creating typical figures of speech. In other words, the director may have been unconsciously searching for the possibility to 
create a figure of speech: indirectly, he succeeded in achieving an artistic effect, because it is just this stylization and deviation from the previous full shot that can give a film additional aesthetic value. Creation in that case comes down to the usage of the figure symbolized in the Latin proverb "pars pro toto".

Finally, we arrive at possibly the most powerful "weapon"in the creation of figures of speech, montage. Unlike real life, explains Arnheim, film allows for jumps within space and time: montage represents the connecting of shots which show situations which have occurred at different times and in different situations. The film image originated from a single process of reproducing reality which, although under man's control, actually represents a copy of nature, its reproduction on screen. However, in montage, notes Arnheim, man assumes control (shots that are unconnected in terms of time and space are linked) which is why montage is most like creation itself, the true process of creating and forming. The director uses montage to underline a real event which is then given a more profound meaning. Here, Arnheim calls upon a scene from Pudovkin's film "Mother".

"I wanted to show joy using film. To simply film a face showing a joyful expression wouldn't be effective in the least. So I showed playful hands and the bottom part of a face: the detail of smiling lips. Alongside this, I edited in other material - for example shots of a colorful spring stream reflecting sunlight playing upon the water... and finally a child laughing. I regarded this as a way to express the prisoners' joy“, said Pudovkin. Arnheim is not convinced of this scene's artistic justification: he is suspicious of whether the symbolic connection between the smile, stream and sunlight, and the "happy prisoner"create visual unity. The German scientist reminds us how "unity" has been achieved in poetry a thousand times, but adds; unrelated topics are easily united because the mental plays provoked by words are much more abstract, and thus easier tied into a whole. To tie together real plays in such a way, in a film that is otherwise realistic, seems somewhat artificial, because the unity of the scene - the story of a rejoicing prisoner - is suddenly distorted by somewhat that is completely beyond the course of events, explains Arnheim. Therefore, he is not convinced of the artistic range of Pudovkin's idea, but does admit that it is an unexpected situation: the shot of the stream, laughter and child does represent a clear deviation from the previous narrative, one based on a real story. Therefore we can determine that this violation of the expected does indeed represent a figure of speech. Maybe not a completely successful figure of speech, if we rely on the German scientist's "evaluation", but a figure of speech nonetheless. We can add that Arnheim, when faced with the aforementioned case, justifiably draws parallels between film and literature in which, he states, such an "ideal solution"(which we will refer to as a figure of speech because it truly is) would be more comprehensible then in film. In literature, it would be a marvelous metaphor. But in film? At least it seems to be an attempt at a beautiful metaphor, through montage. Here, deviation is too obvious in relation to the expected situation because the director failed in preparing enough contextual indicators for the interpretation of function, i.e. the deviation's deeper meaning.

It is through this last example that we are able to best see that Arnheim, speaking of film's artistic achievements, is really speaking of the creation of figures of speech, although unaware of it himself, this was not his intention. It may sound paradoxal, but 
the figures of speech and metaphors became most evident, thus displaying intimate ties with literature, in "not so successful", to use Arnheim's words, artistic endeavors.

\section{Conclusion}

A figure of speech is an addition. It is not necessary. A great deal of classic films has no figures of speech. One explanation is that figures of speech help the viewer in better comprehending the presentation process. In other words, they enhance the perception of especially important moments in the film. In this way, these moments remain remembered longer. If film were to depict life only as it truly was, figures of speech would be unnecessary. Absence of these figures doesn't threaten classic narrations, although in some genres this may cause insecurities to arise. A director who doesn't resort to figures of speech, who shows us only the "world's reality"and does not attempt to subjectively filter that reality can hardly be called - judging by Arnheim's approach - a true artist. He may be a good technician, but we have also observed that Arnheim doesn't place much importance to technical achievements. He is even somewhat suspicious to the appearance of voice on film and is convinced that the true artistic picture is actually silent film.

In silent film, there is no possibility for important situations to be depicted through conversation: the only solution is resorting to what we would today call figures of speech. We can conclude therefore, that it is because of this that examples of an artistic and aesthetic approach in silent films, beginning with Charlie Chaplin's "The Immigrant", are actually examples of figures of speech. Such is created an indirect link between figures of speech and Arnheim's aesthetics theory. Figures of speech contribute to the marking of strategically important places in a film's presentation: they enhance perception of the film and so force the viewer in actively participating in the creation of an artistic experience, which then becomes the yield of interaction between the director's imagination and the viewer's perception. As Arnheim explains, this creates a "visual thought"within the viewer. The absence of figures of speech from the language of film would mean less artistic freedom for the director. Therefore, a "mandatory" inclusion of "deviation", or originality also represents a certain restraint of artistic freedom; it signifies determination of what art is "a priori" and that is something that may be criticized of Arnheim.

\section{Bibliography}

Arnheim, R., Film as Art, Beograd, Narodna knjiga, 1962

Arnheim, R., Art and Visual Perception, Berkeley, California: University of California Press, 1974

Arnheim, R. Visual Thinking, Berkeley-Los Angeles, University of California Press, 1969

Turković, H., Teorija filma, Zagreb, Meandar, 1994 
Turković, H., Film: zabava, žanr, stil, Zagreb, Hrvatski filmski savez, 2005

Perniola, M., Estetika XX stoljeća, Odjeka, 2006

Metodički obzori 10, vol. 5(2010)2

Pregledni rad

UDK: 159.954:111.852>:7

Primljeno: 6. 12. 2009.

\section{ARNHEIMOVA ESTETSKA TEORIJA I STILSKE FIGURE}

Dario Saftich, $B A$

e-mail: dario.saftich@htnet.hr

Edit, Rijeka (Croatia)

\section{Sa žetak}

Kad je 1932. godine izašla knjiga njemačkoga znanstvenika Rudolpha Arnheima "Film kao umjetnost" predstavljala je značajan doprinos teorijskoj debati o filmu kao umjetnosti. Arnheim je bio jedan od onih koji su otvorili raspravu: suprotstavio se podrazumijevanom otpisivanju filma iz kruga umjetnosti. Prema Arnheimovu mišljenju između percepcije realnosti i percepcije njezine reprodukcije na filmskom platnu postoje velike različitosti i upravo u tim različitostima treba tražiti umjetničke mogućnosti koje se otvaraju filmu. Rudolph Arnheim, u ovom kontekstu, ne govori o filmskim figurama, međutim raščlanjujući njegove teorijske pretpostavke i filmske primjere koje navodi kao prilog tezi o filmu kao umjetnosti, otkriva se posredna iznenađujuća veza između njegove vizije mogućih umjetničkih dostignuća filma i stilskih figura u filmu. Književne figure, objašnjava nam posredno Arnheim, ne mogu se mehanički pretočiti u filmske. Međutim redatelj može postati umjetnik koji će nam predočiti svijet ne takav kakav objektivno izgleda, nego i subjektivno: on je u stanju stvarati nove realnosti, evocirati čarobne svjetove, stvarati simbolične mostove između činjenica i stvari među kojima u realnom životu ne postoji neposredna veza. Rudolf Arnheim prenio je pojam Gestalt, kako ga je razvila gestalt-psihologija, i na estetiku.

Ključne riječi: film, umjetnost, realnost, percepcija, reprodukcije, stilske figure, književne figure, estetika 